\title{
MPO Negative
}

National Cancer Institute

\section{Source}

National Cancer Institute. MPO Negative. NCI Thesaurus. Code C162080.

An indication that expression of MPO has not been detected in a sample. 